\title{
Contraceptive Use and Its Socio-economic Determinants among Women in North-East and North-West Regions of Nigeria: A Comparative Analysis
}

\author{
Godwin Unumeri $^{1 \mathrm{a}}$; Salisu Ishaku ${ }^{\mathrm{a}}$; Babatunde Ahonsi ${ }^{\mathrm{b}}$ and Ayodeji Oginni ${ }^{\mathrm{a}}$ \\ ${ }^{a}$ Population Council, 16, Mafemi Crescent, Utako District, Abuja, Nigeria. \\ Email: gunumeri@popcouncil.org Tel. No.+234-803-3601660 \\ ${ }^{\mathrm{b}}$ UNFPA, Ghana
}

\begin{abstract}
This study investigated the socio-economic factors associated with reported contraceptive use by women of reproductive age in northern Nigeria. Bivariate and logistic regression analysis was applied to successive Nigeria Demographic and Health Survey (NDHS: 1999-20/3) data to examine the relationship between reported use of modern contraceptives (the dependent variable) and the socioeconomic status (age, rural-urban residence, education, religion, current work status, marital status, and number of living children) of these women in the north-east (NE) and north-west (NW) geo-political zones (GPZs). The results indicated that women's socio-economic status were positively associated with use of modern contraceptives in the $N W$ in 1999 ( $A O R=2.15 ; 95 \% \mathrm{Cl}=1.47,3.14), 2003$ $(A O R=1.64 ; 95 \% \mathrm{Cl}=1.30,2.08)$ and $2013(A O R=1.30 ; 95 \% \mathrm{Cl}=1.12,1.50)$ and also in the north-east in 2008 ( $A O R=0.74 ; 95 \% \mathrm{Cl}=0.64,0.86)$. Contraceptive use could increase as FP programmes better respond to the socio-economic and cultural circumstances of women in northern Nigeria.
\end{abstract}

Keywords Contraceptive use, socio-economic determinants, Northern Nigeria

\section{Résumé}

Cette étude examine les facteurs socio-économiques associés avec l'usage des contraceptifss parmi les femmes en âge de procréer dans le Nord du Nigéria. La régression bivariée et logistique a été appliquée sur les données démographiques de santé receuillies au Nigeria entre: 1999-2013. avec le but d'établirla relation entre a l'usage des contraceptifs modernes (la variable dépendante) et une gamme de facteurs socio-économiques (âge, le lieu de résidence rurale-urbaine, éducation, religion, l'emploi,, l'état matrimonial et le nombre d'enfants vivants) dans le Nord-Est (NE) et Nord-Ouest (NO) du Nigeria.. Les résultats ont démontré une association positive entre l'émancipation socioéconomique des femmes et l'usage $r$ des contraceptifs modernes dans NO en 1999 (AOR = 2.15; $95 \% \mathrm{Cl}=1.47,3.14), 2003(\mathrm{AOR}=1,64 ; 95 \% \mathrm{Cl}=1.30,2,08)$ puis $2013(\mathrm{AOR}=1,30 ; 95 \% \mathrm{Cl}=1.12$, 1.50), mais seulement en $2008(A O R=0,74 ; 95 \% C l=0.64,0,86)$ dans le $N E$. L'utilisation des contraceptifs modernes pourrait augmenter dans le Nord du Nigéria si les projects de plannification familiale améliorent l'etat socio-economique de la femme

Mots-clés: Contraception, déterminants socio-économiques, nord du Nigeria

\footnotetext{
${ }^{1}$ Corresponding Author
} 


\section{Introduction}

Nigeria became an independent nation on October I, 1960 following a 46-year period that started with the amalgamation of its northern and southern protectorates in 1914. Governed from a Federal Capital Territory (FCT) created in 1991, the Federal Republic of Nigeria (FRN) is made up of 36 states further divided into 774 constitutionally recognized local government areas (LGAs) and six geo-political zones namely; north-west, north-east, north-central, south-west, south-south and the south-east. Its 923,768 square kilometer landmass is inhabited by an estimated population of 173 million people (2014). Latest estimates put its growth rate and life expectancy for both sexes at $3.2 \%$ per annum and 52 years respectively. Childbearing age adults (15 - 49) represent $24 \%$ of its total population that is made up of approximately equal proportions of male and female. Oil and gas account for more than $75 \%$ of its huge annual revenue, $38.8 \%$ of its GDP and a projected $6.0 \%$ growth in real GDP (CBN, 2002).

Yet, Nigeria is faced by a high maternal mortality situation due to persistent cases of post-partum hemorrhage, unsafe abortion, obstructed labour, preeclampsia/eclampsia, malaria and anaemia that could be effectively managed with low cost interventions (NPC and Marco, 20I3; Ndep, 2014) such as the range of contraceptives obtainable in the country and elsewhere. However, it has been consistently found that women of high socio-economic status are more likely to use modern contraceptives for delaying, spacing and limiting childbearing completely and enjoy its attendant benefits like the reduction in maternal/infant mortality, decline in unsafe abortion and decrease in unintended pregnancy rate. Others comprise of a drop in sexually transmitted infections including the human immunodeficiency virus (HIV), improvement in women's autonomy, education, welfare, community health and a fall in the population growth rate (WHO, 20I3). In addition to empowering families and saving the lives of children and women in their reproductive years, communitywide use of modern contraceptives could promote the achievement of national development goals (Fotso et al. 20II).

Despite these accruable contraceptive use benefits, Nigeria's contraceptive prevalence rate (CPR) for modern methods has only marginally risen from $3.5 \%$ in 1990 to $10 \%$ in 2013 (NPC and Macro, 1999; 2003; 2008; 2013). It is therefore not surprising that there has only been a small reduction in total fertility rate (TFR) from 6.0 (1990) to 5.5 (2013) accompanied by persistently high maternal (MM) and child mortality (CM) rates (at 576/100,000 live births and $128 / I, 000$ live births respectively).
However, reproductive health and family planning indices in Nigeria vary widely across the six geopolitical zones (GPZs). For example, evidence from the 2013 NDHS reveals that women residing in the South-West, South-South and South-East have higher modern CPRs (38\%, $28 \%$ and $29 \%$ respectively) compared to those in the North-Central North-East and the North-West (16\%, 3\% and 4\% respectively). This study seeks to compare contraceptive use and its socio-economic determinants among women between two northern regions (NW and NE) in the country over a period of 14 years (1999-2013). In the rest of this paper we briefly review the existing literature, state the key study questions and present the results before the discussion and concluding sections follow.

\section{Background to the Study}

All local communities are governed by a set of norms and values that define culturally approved conduct. For most of the communities in the northern GPZs of Nigeria where Islam is widespread, religion largely defines appropriate social behaviour, particularly the decision by women to either use or abstain from the use of contraceptives. Generally, Islam does not forbid family planning (FP) but prefers to emphasize the spacing component at "individual family level" for "medical reasons" certified by qualified health care providers, who may not necessarily be Muslims (NURHI, 2004). Tenets of Islam advise post-partum FP (PPFP) "to prevent the mother from becoming pregnant immediately after delivery (Kwanika) before weaning" because "it helps to avoid the possibility of developing complications that could affect the mother and even the sibling." But more importantly, a fatwa supports outright limiting of child birth for women with life-threatening conditions like "multiple caesarean sections, ruptured uterus, psychosis and sickle cell disease" (NURHI, 2004). Furthermore, Islam recommends the voluntary practice of traditional methods of FP such as withdrawal or coitus interruptus (al' azl) and prolonged breastfeeding to its followers (Erulkar and Bello 2007). Some Islamic scholars (Ulama) accept al' azl' as an endorsement for the use of barrier methods of FP, with the consent of wives (NURHI, 2004), while others argue that "for a religious leader to come out and ask his flock to use a condom, for instance, in the name of safe sex is akin to giving them a blank cheque to be promiscuous, which negates our religious duty to ensure people remain morally upright (IRIN News, 20II)." The Ulama unanimously condemned vasectomy but emphasise that women may use modern methods like tubal ligation as well as implants and oral contraceptives on health grounds (NURHI, 
2004). Studies conducted across several sociocultural settings of Africa have also identified the use of sex taboos to encourage birth-spacing in addition to preventing women from getting pregnant for specific lengths of time, postpartum, to forestall the pollution of their breast-milk (Odimegwu, 1994) and ultimately promote children and women's survival and health (Caldwell and Caldwell, 1977; Van de Walle and Van de Walle, 1989).

Despite these progressive interpretations, there remain socio-cultural norms that prove problematic for women in particular. Islam recommends polygyny to those who can afford to manage the economic challenges and demands for affection that come with it. Polygyny remains a status symbol that fosters procreation in a setting where children are still largely needed for farm labour and their intrinsic value. Moreover, there is strong preference for the male child (Olurode, 1998) though Islam prescribes proper care and protection for the girl-child in the family.

In most northern communities girls are encouraged into early marriage as a form of control against premarital sex and the stigma it brings to the family (Wall, 1998). Customarily, girls are given out in marriage to older men, and this significantly reduces their social status and decision-making power because of the shifts in priority from education, income earning and life-skills acquisition to motherhood and family life preoccupation that marriage entails (Mensah et al. 1988). Marriage comes with Kulle or Purdah, that is, restriction of women to their husbands' houses together with Kunya or expectation that women demonstrate modesty or shyness before men, elders, parents, inlaws and outsiders (Erulkar and Bello, 2007). Islam also prohibits "the issue of a male doctor examining or attending to a female patient" except in situations where there are no female health care providers or the lives of the mother and her unborn child are threatened. Additionally, a woman may only have an abortion to save her life.

What has become clear, from the foregoing, is that these practices could further complicate the already high incidence of home deliveries, maternal morbidity/mortality and missed opportunity for PPFP in northern Nigeria. Women's all-round decisionmaking ability is further weakened by denial of title to land and lack of compensation for their work in husbands' farms and households. Thus, faced with pervasive poverty women introduce their girls into hawking in order to earn little incomes to support their homes. The overall implication is that most women in northern Nigeria have limited access to formal education and self-empowerment opportunities which drastically limits their ability to make independent contraceptive use decisions.
It has been empirically established that there is strong relationship between socio-demographic factors and the use of contraceptives (Adebowale, 2013; Fotso et al 201I, Odimegwu 1997). Illustrations from global data clearly indicate that reduction in the TFR from 5.0 to 2.6 between the 1950 s and 2010 resulted mainly from the variations in contraceptive use by more rapidly developing countries (DCs) compared to the less developing ones (LDCs) (Population Bureau, 2009). They further indicate that, as a result of the high incidence of poverty and low CPR, maternal mortality occurs to one in every twenty-six women of childbearing age in Africa. Lessons from Asian countries also confirm that widespread contraceptive use for FP coincided with massive investment in socio-economic and human development, complemented with improved contraceptive security (Duze and Mohammed, 2006). Within sub-Saharan Africa, studies have equally implicated socio-demographic factors such as age, parity, education, religion, place of residence, current work, marital status, spousal communication and other variables for observed differences in the use of contraceptives by women (Fotso et al. 2014; NPC and Marco, 2013; Odimegwu et al, 1997; Adebowale et al, 2013; Omo-Aghoja, 2009).

Research literature on the determinants of contraceptive use among women in Nigeria clearly show a glaring north-south divide based on their demographic and socio-economic status differentials. A national study among rural and urban residents that shed light on ever use of modern contraceptives and the number of living children among other proximate determinants of fertility rated the three GPZs of the south better on all the variables (Fotso et al. 20II). Key findings of the study were that due to rapid improvement in the socio-demographic status of women such as age, modern contraceptive knowledge, parity, source, use intentions, mass media exposure, spousal communication and family planning attitudes, the CPR gap between the southern and northern GPZs continues to widen in favour of the former. Another study on regional correlates of choice of traditional and modern contraceptive methods arrived at the same conclusion (Odimegwu et al, 1997). This study found that women in the southern states were more receptive to FP because higher proportions of them were educated, lived in urban settings, identified as Christians, married relatively late and consented to FP. Paradoxically, it also concluded that ever use and current use remained low in the northern zones even with an increase in knowledge of contraceptive methods relative to the levels in the south-western and south-eastern zones. Adebowale et al. surmised that a "higher proportion of women who currently 
used contraception was found in all the regions in the southern part of Nigeria than any of the regions in the north" (Adebowale et al. 2013). Variables that informed the study conclusions included age, religion, residence, education, marital status and husband's education. Slightly different dimensions of contraceptive use determinants were introduced by other studies. Omo-Aghoja implicates the level of ignorance, degree of communication with spouses and consent obtained, fear of side effects, and adequacy of information for the extent to which women would use contraceptives (Omo-Aghoja, 2009). For Oyedokun, education of women constitutes the most critical factor in contraceptive use (Oyedokun, 2007). Makinwa-Adebusoye et al found that the differences in the status of women, which is higher for southern Yoruba, lbo, and ljaw women compared to their northern Kanuri and Hausa counterparts were associated with spousal disagreement in fertility decision-making. According to this study, there was "higher levels of communication and joint decision-making among the Yoruba, lbo, and ljaw compared with the Kanuri and Hausa groups in which most husbands and wives (about $80 \%$ ) agree that they never talk about family planning and that the wife has no say on family size issues." Correspondingly, "Kanuri and Hausa wives were found to be significantly less likely to indicate that they use or will use family planning," even when the study controlled for fertility desires, communication on family planning and wife's say and other socio-economic characteristics (MakinwaAdebusoye et al, 1997).

A glaring limitation that has emerged from this review of the existing empirical and interpretative studies is their tendency to consider, in broad terms, the relationship between socio-economic status and contraceptive use in ways that portray the advantages of southern women over their northern counterparts. With this paradigm, these studies have repeatedly glossed over the critical social, cultural and religious contexts and dynamics within which FP decisions are made. Several studies (Sule, Umar, and Madunagu 2006; Odimegwu, 1997) have also identified differences in the contraceptive use patterns of women in northern GPZs based on their unequal socioeconomic status. However, most of these studies were done in small community settings, which limit their representativeness and relevance for policy formulation. It is in this regard that we seek to examine if there are inter-regional differentials in contraceptive use within northern Nigeria, where values and social meanings are shared, and if these variations are related to differentials in socioeconomic status. We also desire to identify some common factors and opportunities that might be leveraged on to expand the use of contraceptives in northern Nigeria. For the purpose of clarity the study was guided by two key questions:

I. What was the relationship between the socio-economic status of women and their reported use of contraceptives in northern Nigeria? and

II. What recommendations could we put forward to promote the rapid use of contraceptives among women in northern Nigeria?

\section{Conceptual framework:}

The conceptual framework of this study was primarily predicated on the comparative analysis of modern contraceptive use among women between the two regions, NE and NW Nigeria. However, the influence of some demographic (age and parity), socio-economic (marital status, current work status, religious affiliation and education) factors, rural-urban residence and region of residence (NW and NE) was considered in order to clearly understand the differential in contraceptive use between NE and NW women in Nigeria over the period of time under consideration (Figure I). Younger age women, especially those just beginning to bear children in marriage are less likely to use contraceptives compared to the relatively older ones. Furthermore, women resident in urban areas tend to use contraceptives more due to improved access to multiple sources of commodities. While education empowers women to acquire information to use contraceptives in appropriate ways, this prospect is further boosted for those who can afford FP commodities because they are currently working. As their parity or number of living children increase women tend to increase use of contraceptives for family size limitation. Similarly, the religious beliefs of women influence their decision to either use or abstain from contraceptives in general. 


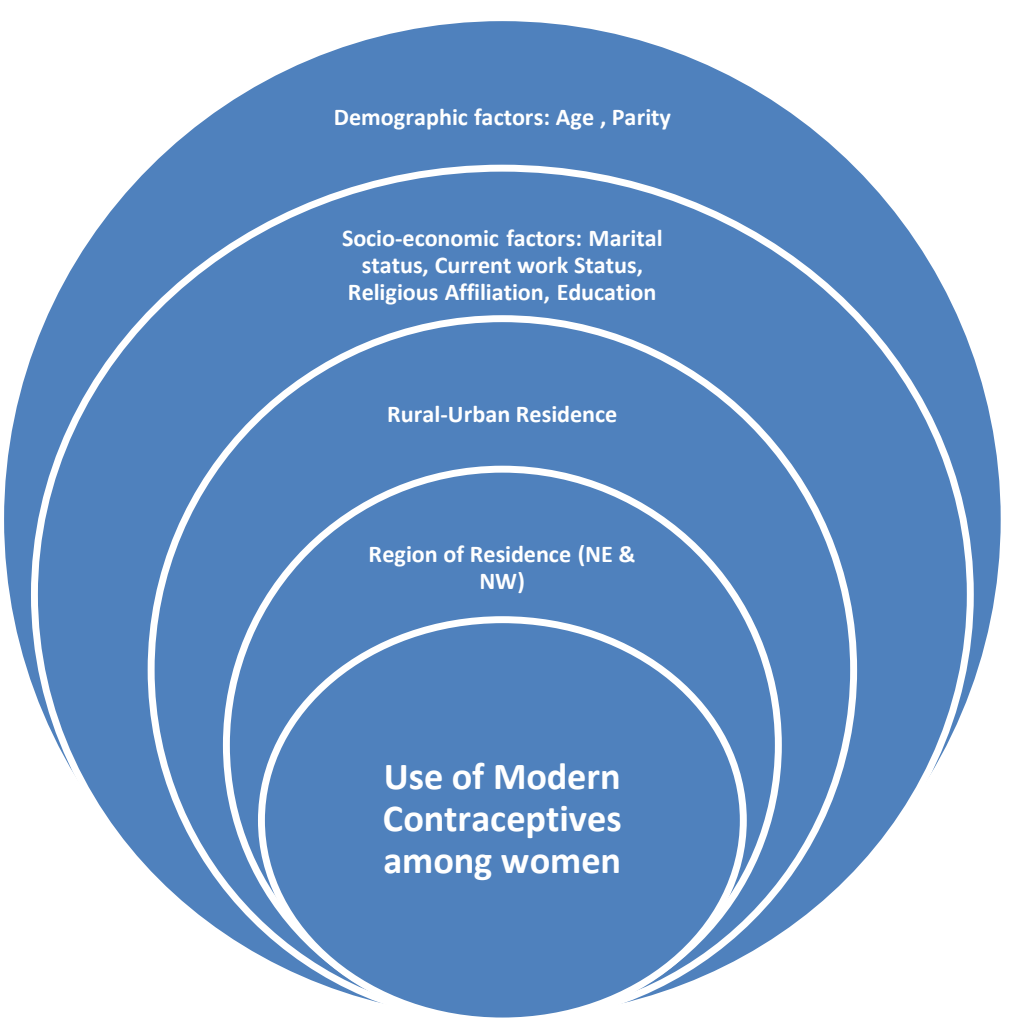

\section{Methodology}

\section{Study population \& Data sources:}

Secondary data analysis was conducted on the northwest and north-east women data extracted from the 1999, 2003, 2008 and 2013 Nigeria Demographic and Health Surveys (NDHS). The data were obtained on request from ORC DHS Measure. The study population comprised women of reproductive age (15-49) residing in northern Nigeria. Therefore, the study dataset was restricted to data collected from women residing in the North-East (NE) and NorthWest (NW) geopolitical zones of Nigeria. These two zones represent the core north and share broadly similar social, cultural and religious realities distinct from the north-central (NC) which is more or less a melting pot for northern and southern cultures. The study dataset contains records of $1292 \mathrm{NE}$ and 1087 NW women from the 1999 NDHS; $1368 \mathrm{NE}$ and 2094 NW women from the 2008 NDHS; and 5766 NE and I I 877 NW women from the 2013 NDHS.

\section{Dependent and Independent Variables}

The dependent variable of interest in the study was "Ever used a modern contraceptive". The variable was derived from the primary variable "Ever used any method" which contains the following categories of response: 0-“Never used", I-“Used only folkloric",
2-"Used only traditional method", and 3-“Used modern method".

The independent variables of interest in this study were respectively demographic (age and parity), socio-economic (educational level, religion, current work status, marital status) and geographic variables (geo-political zone and rural-urban residence). The selection of these few independent variables was informed by evidence in the literature and the availability of these variables in the study dataset.

\section{Statistical Analysis and Model}

The demographic and socio-economic status characteristics and contraceptive use among the study respondents in the two regions were compared for each successive study year using Chi-square test $(p<0.005)$. Subsequently, bivariate analysis was also conducted with Chi-square test to identify factors that were significantly associated with contraceptive use among the study population in each study year. Multivariate analyses were conducted using binary logistic regression to: (I) compare contraceptive use between NE and NW women controlling for the demographic and SES characteristics for each study year; and (2) identify significant determinants of contraceptive use among NE women and NW women for each study year. Estimates are presented in Odds ratios with $95 \%$ Confidence Intervals. 
Logit $\left(P_{i}\right)=\ln \left(\frac{P_{i}}{1-P_{i}}\right)=\beta_{0}+\beta$ (Region) $+\beta($ Age $)+\beta($ Residence $)+\beta$ (Education $)+\beta$ (Religion $)+\beta($ Works $)+$ $\beta$ (Marital) $+\beta$ (Parity)

Logit $\left(P_{i}\right)=\ln \left(\frac{P_{i}}{1-P_{i}}\right)=\beta_{0}+\beta($ Region $)+\beta($ Age $)+\beta$ (Residence $)+\beta$ (Education $)+\beta$ (Religion $)+\beta($ Works $)+$ $\beta$ (Marital) $+\beta$ (Parity).

Logit $\left(P_{i}\right)=\ln \left(\frac{P_{i}}{1-P_{i}}\right)=\beta_{0}+\beta$ (Region) $+\beta($ Age $)+\beta$ (Residence $)+\beta$ (Education $)+\beta$ (Religion $)+\beta($ Works $)+$ $\beta($ Marital) $+\beta$ (Parity)

Logit $\left(P_{i}\right)=\ln \left(\frac{P_{i}}{1-P_{i}}\right)=\beta_{0}+\beta$ (Region) $+\beta($ Age $)+\beta$ (Residence $)+\beta$ (Education $)+\beta$ (Religion $)+\beta($ Works $)+$ $\beta($ Marital) $+\beta$ (Parity)

Logit $\left(P_{i}\right)=\ln \left(\frac{P_{i}}{1-P_{i}}\right)=\beta_{0}+\beta$ (Age) $+\beta$ (Residence) $+\beta$ (Education $)+\beta$ (Religion $)+\beta($ Works $)+\beta($ Marital $)+$ $\beta$ (Parity). .(NE Women, 1999)

Logit $\left(P_{i}\right)=\ln \left(\frac{P_{i}}{1-P_{i}}\right)=\beta_{0}+\beta$ (Age) $+\beta$ (Residence) $+\beta$ (Education $)+\beta$ (Religion $)+\beta($ Works $)+\beta($ Marital $)+$ $\beta$ (Parity). ..(NW Women, 1999)

Logit $\left(P_{i}\right)=\ln \left(\frac{P_{i}}{1-P_{i}}\right)=\beta_{0}+\beta($ Age $)+\beta$ (Residence) $+\beta$ (Education $)+\beta$ (Religion $)+\beta($ Works $)+\beta($ Marital $)+$ $\beta$ (Parity) .(NE Women, 2003)

Logit $\left(P_{i}\right)=\ln \left(\frac{P_{i}}{1-P_{i}}\right)=\beta_{0}+\beta$ (Age) $+\beta$ (Residence) $+\beta$ (Education $)+\beta$ (Religion $)+\beta($ Works $)+\beta($ Marital $)+$ $\beta$ (Parity). (NW Women, 2003)

Logit $\left(P_{i}\right)=\ln \left(\frac{P_{i}}{1-P_{i}}\right)=\beta_{0}+\beta$ (Age) $+\beta$ (Residence) $+\beta$ (Education $)+\beta$ (Religion $)+\beta($ Works $)+\beta$ (Marital $)+$ $\beta$ (Parity). .(NE Women, 2008)

Logit $\left(P_{i}\right)=\ln \left(\frac{P_{i}}{1-P_{i}}\right)=\beta_{0}+\beta($ Age $)+\beta$ (Residence $)+\beta$ (Education $)+\beta($ Religion $)+\beta($ Works $)+\beta($ Marital $)+$ $\beta$ (Parity). ...(NW Women, 2008)

Logit $\left(P_{i}\right)=\ln \left(\frac{P_{i}}{1-P_{i}}\right)=\beta_{0}+\beta($ Age $)+\beta$ (Residence) $+\beta$ (Education $)+\beta$ (Religion $)+\beta($ Works $)+\beta($ Marital $)+$ $\beta$ (Parity). .(NE Women, 2013)

Logit $\left(P_{i}\right)=\ln \left(\frac{P_{i}}{1-P_{i}}\right)=\beta_{0}+\beta$ (Age) $+\beta$ (Residence) $+\beta$ (Education $)+\beta$ (Religion $)+\beta($ Works $)+\beta($ Marital $)+$ $\beta$ (Parity) ..(NW Women, 20I3)

Where $P_{i}$ is the odds of ever used a modern contraceptive and the independent variables in the models were geopolitical region of residence (Region), age (Age), rural-urban residence (Residence), highest education (Education), religious affiliation (Religion), current work status (Work), marital status (Marital), and number of living children (Parity).

\section{Results}

\section{Demographic and socio-economic characteristics of} the study population

Table I shows the distribution of the study population from North-east (NE) and North-west
(NW) GPZs by some selected characteristics for the four survey years - 1999, 2003, 2008 and 2013. Young respondents (age 15-24) accounted for not less than $35 \%$ of the study population. There is a discernible drop in the percentage of respondents with an increase in the age of sampled population from age group 15-19 to 45-49 across the models in both GPZs. Over $70 \%$ of the respondents resided in rural areas. Of each survey study population, more than two-thirds had no formal education; over $75 \%$ practiced Islam; more than $42 \%$ were currently working; over $80 \%$ were currently married and not less than one-third reportedly had 2-4 living children. 
Table I: Demographic and socio-economic characteristics of respondents by year of survey

\begin{tabular}{|c|c|c|c|c|c|c|c|c|c|c|c|c|}
\hline & \multicolumn{2}{|c|}{1999} & \multirow[b]{2}{*}{$\mathrm{p}$-value } & \multicolumn{3}{|c|}{2003} & \multicolumn{2}{|c|}{2008} & \multirow[b]{2}{*}{$\mathrm{p}$-value } & \multicolumn{2}{|c|}{2013} & \multirow[b]{2}{*}{$\mathrm{p}$-value } \\
\hline & $\begin{array}{l}\text { NE } \\
\% \\
\end{array}$ & $\begin{array}{l}\text { NW } \\
\% \\
\end{array}$ & & $\begin{array}{l}\text { NE } \\
\% \\
\end{array}$ & $\begin{array}{l}\text { NW } \\
\% \\
\end{array}$ & $\mathrm{p}$-value & $\begin{array}{l}\text { NE } \\
\% \\
\end{array}$ & $\begin{array}{l}\text { NW } \\
\% \\
\end{array}$ & & $\begin{array}{l}\text { NE } \\
\% \\
\end{array}$ & $\begin{array}{l}\text { NW } \\
\%\end{array}$ & \\
\hline \multicolumn{13}{|l|}{ Age } \\
\hline $15-19$ & 20.8 & 18.4 & 0.546 & 21.5 & 20.0 & 0.522 & 20.1 & 17.2 & 0.002 & 20.6 & 20.4 & 0.039 \\
\hline $20-24$ & 19.3 & 22.3 & & I8.1 & 18.9 & & 17.7 & 18.6 & & 18.5 & 17.2 & \\
\hline $25-29$ & 19.1 & 19.4 & & 17.8 & 17.7 & & 18.9 & 18.2 & & 18.4 & 18.1 & \\
\hline $30-34$ & 15.2 & 14.6 & & 13.2 & 13.7 & & 13.5 & 14.7 & & 13.6 & 13.7 & \\
\hline $35-39$ & 13.0 & 12.2 & & 11.7 & 11.9 & & 11.8 & 11.7 & & 11.8 & 11.8 & \\
\hline $40-44$ & 8.0 & 8.2 & & 9.1 & 10.6 & & 9.2 & 10.0 & & 8.7 & 9.0 & \\
\hline $45-49$ & 4.6 & 4.9 & & 8.5 & 7.1 & & 8.9 & 9.6 & & 8.4 & 9.8 & \\
\hline \multicolumn{13}{|l|}{ Residence } \\
\hline Urban & 20.0 & 16.4 & 0.000 & 27.5 & 27.8 & 0.846 & 26.3 & 20.4 & 0.000 & 27.4 & 28.6 & 0.081 \\
\hline Rural & 71.0 & 83.6 & & 72.5 & 72.2 & & 73.7 & 79.6 & & 72.6 & 71.4 & \\
\hline \multicolumn{13}{|l|}{ Highest education } \\
\hline No formal education & 76.9 & 82.3 & 0.006 & 67.8 & 75.0 & 0.000 & 68.1 & 74.2 & 0.000 & 64.4 & 69.4 & 0.000 \\
\hline Primary & 8.9 & 8.1 & & 16.5 & 11.8 & & 15.5 & 11.8 & & 13.7 & 11.6 & \\
\hline Secondary & 12.1 & 8.4 & & 13.3 & 10.9 & & 14.3 & 11.4 & & 17.0 & 16.5 & \\
\hline Higher & 2.1 & I.3 & & 2.4 & 2.2 & & 2.2 & 2.6 & & 4.9 & 2.5 & \\
\hline \multicolumn{13}{|l|}{ Religion } \\
\hline Christianity & 12.1 & 9.6 & 0.143 & 15.9 & 4.8 & 0.000 & 20.9 & 7.7 & 0.000 & 16.1 & 9.6 & 0.000 \\
\hline Islam & 87.2 & 89.8 & & 82.4 & 94.8 & & 77.4 & 90.2 & & 83.3 & 89.7 & \\
\hline Others & 0.7 & 0.6 & & 1.7 & 0.4 & & 1.6 & 2.1 & & 0.6 & 0.7 & \\
\hline \multicolumn{13}{|l|}{ Current working } \\
\hline No & 79.6 & 79.5 & 0.961 & 50.0 & 48.5 & 0.424 & 42.9 & 54.0 & 0.000 & 54.0 & 42.4 & 0.000 \\
\hline Yes & 20.4 & 20.5 & & 50.0 & 51.5 & & 57.1 & 46.0 & & 46.0 & 57.6 & \\
\hline \multicolumn{13}{|l|}{ Marital status } \\
\hline Never married & 9.6 & 6.3 & 0.012 & 12.4 & 6.9 & 0.000 & 12.4 & 7.8 & 0.000 & 14.6 & 12.4 & 0.000 \\
\hline Currently married & 88.0 & 90.7 & & 82.1 & 89.7 & & 84.1 & 89.6 & & 81.1 & 84.5 & \\
\hline Formerly married & 2.4 & 2.9 & & 5.6 & 3.3 & & 3.5 & 2.6 & & 4.3 & 3.1 & \\
\hline \multicolumn{13}{|c|}{ Number of living children } \\
\hline 0 & 21.2 & 20.4 & 0.072 & 22.5 & 21.8 & 0.055 & 21.7 & 19.3 & 0.007 & 25.3 & 22.7 & 0.000 \\
\hline I & 17.0 & 19.8 & & 16.0 & 16.8 & & 13.4 & 13.9 & & 12.9 & 12.8 & \\
\hline
\end{tabular}




\section{Ever use of modern contraceptives and associated factors}

The proportions of female respondents from the NE and NW GPZs, who reported that they had ever used modern contraceptives varies from one survey to the other. As of 1999, there was no significant difference $(6.5 \%$ vs. $8.2 \%, p=0.115)$ between NE and NW in terms of the proportion of women who reported ever using modern contraceptives. In 2003, the level of ever use of modern contraceptives among female respondents was significantly higher in NW than NE (14.4\% vs. II.2\%; $p=0.007) .2008$ proportions of this category of respondents generally fell below the 2003 levels though the fall gradient was steeper in the NW than NE (6.4\% vs. $10.0 \%)$. Data from the 2013 survey brings the NE and NW GPZs to parity $(7.2 \%$ vs. $7.5 \%)$ in reported ever use of modern contraceptives.

Table 2 shows the pattern of ever use of contraceptives by some selected demographic and socio-economic characteristics. Among the age categories, those aged 15-19 had the lowest percentages of those who reported ever use of contraceptives in 1999, 2003, 2008 and 2013. Consistently across the four surveys, higher proportions of women residing in urban areas reported ever use of contraceptives. Having ever used contraceptives increased significantly with educational status and increasing number of living children in all survey years (1999-2013). A higher proportion of Christian women reported ever use of modern contraceptives than their Muslim peers in all survey years. Ever use of modern contraceptives was lower among the never married women compared to the currently and formerly married, except in 2013 where the proportion among formerly married women is lowest. Those currently working also reported higher ever use of modern contraceptives compared to those not currently working.

\section{Binary Logistic Regression Analysis}

Tables 3 and 4 present logistic regression models of factors associated with ever use of contraceptives among the respondents. Table 3 shows that in 1999 $(A O R=2.15 ; 95 \% \mathrm{Cl}=1.47,3.14), 2003(\mathrm{AOR}=1.64$; $95 \% \mathrm{Cl}=1.30,2.08)$ and $2013 \quad(\mathrm{AOR}=1.30$; $95 \% \mathrm{Cl}=\mathrm{I} .12, \mathrm{I} .50$ ), women in the $\mathrm{NW}$ were more likely to have ever used contraceptives than women in the NE; whereas in 2008 ( $A O R=0.74$; $95 \% \mathrm{Cl}=0.64,0.86)$, women in the $\mathrm{NW}$ were less likely to have ever used contraceptives than those in NE after controlling for confounding effects of the selected demographic and socio-economic factors. Examining the 1999 models in Table 4, rural-urban residence, educational status, religion and number of living children were significant determinants of having ever used contraceptives among women in both the NE and NW while current work status had no significant association with having ever used contraceptives among women in NE, except in 2013 when the currently working women in NW were found more likely $(A O R=2.35 ; 95 \% \mathrm{Cl}=1.36,4.08)$ to have ever used contraceptives than non-currently working women in the region. In the 2003 models (Table 4), having ever used contraceptives was significantly associated with educational status, religion and number of living children in both the NW and NE. Specifically in the NW, currently working women were more likely $(\mathrm{AOR}=1.83 ; 95 \% \mathrm{Cl}=\mathrm{I} .48$, 2.25) to have ever used contraceptives than noncurrently working women; also rural women were less likely $(A O R=0.38 ; 95 \% \mathrm{Cl}=0.3 \mathrm{I}, 0.46)$ to have ever used contraceptive than urban women, particularly in the NE. In the 2008 and 2013 models, age, rural-urban residence, education, religion (to a lesser extent in 2013) and number of living children were significant determinants of having ever used contraceptives among women in the NE and NW respectively. Likewise, in the 2013 models, currently working women were more likely $(\mathrm{NE}: \mathrm{AOR}=1.77$; $95 \% \mathrm{Cl}=1.29,2.15$ and $\mathrm{NW}: \mathrm{AOR}=1.83 ; 95 \% \mathrm{I} .48$, $2.25)$ to have ever used contraceptive than noncurrently working women. 
Table II: Percentage who reported ever used a modern contraceptive by selected demographic and socio-economic characteristics

\begin{tabular}{|c|c|c|c|c|c|c|c|c|}
\hline & \multicolumn{2}{|c|}{ Year 1999} & \multicolumn{2}{|c|}{ Year 2003} & \multicolumn{2}{|c|}{ Year 2008} & \multicolumn{2}{|c|}{ Year 2013} \\
\hline & $\%$ & $\mathrm{p}$-value & $\%$ & $\mathrm{p}$-value & $\%$ & $\mathrm{p}$-value & $\%$ & $\mathrm{p}$-value \\
\hline \multicolumn{9}{|l|}{ Age } \\
\hline $15-19$ & 2.6 & 0.000 & 2.8 & 0.000 & 2.1 & 0.000 & 4.8 & 0.000 \\
\hline $20-24$ & 5.7 & & 11.0 & & 6.7 & & 18.1 & \\
\hline $25-29$ & 9.0 & & 18.6 & & 10.1 & & 20.8 & \\
\hline $30-34$ & 11.3 & & 18.5 & & 10.7 & & 20.6 & \\
\hline $35-39$ & 11.6 & & 19.6 & & 9.4 & & 16.7 & \\
\hline $40-44$ & 5.2 & & 14.7 & & 9.6 & & 11.7 & \\
\hline $45-49$ & 5.3 & & 11.7 & & 6.4 & & 7.4 & \\
\hline \multicolumn{9}{|l|}{ Residence } \\
\hline Urban & 15.6 & 0.000 & 19.1 & 0.000 & 13.9 & 0.000 & 59.9 & 0.000 \\
\hline Rural & 4.8 & & 10.8 & & 5.8 & & 40.1 & \\
\hline \multicolumn{9}{|l|}{ Highest education } \\
\hline No formal education & 3.7 & 0.000 & 10.2 & 0.000 & 4.4 & 0.000 & 25.1 & 0.000 \\
\hline Primary & 13.8 & & 13.9 & & 11.2 & & 18.9 & \\
\hline Secondary & 19.9 & & 24.6 & & 16.8 & & 39.1 & \\
\hline Higher & 63.4 & & 40.5 & & 37.2 & & 16.9 & \\
\hline \multicolumn{9}{|l|}{ Religion } \\
\hline Christianity & 30.5 & 0.000 & 26.0 & 0.000 & 22.5 & 0.000 & 57.6 & 0.000 \\
\hline Islam & 4.4 & & 11.8 & & 5.5 & & 42.2 & \\
\hline Others & 12.5 & & 9.4 & & 7.2 & & 0.2 & \\
\hline \multicolumn{9}{|l|}{ Current working } \\
\hline No & 5.0 & 0.000 & 8.5 & 0.000 & 5.8 & 0.000 & 25.3 & 0.000 \\
\hline Yes & 16.2 & & 17.6 & & 9.5 & & 74.7 & \\
\hline \multicolumn{9}{|l|}{ Marital status } \\
\hline Never married & 5.2 & 0.273 & 3.8 & 0.000 & 5.2 & 0.000 & 14.6 & 0.217 \\
\hline Currently married & 7.3 & & 14.1 & & 7.8 & & 81.7 & \\
\hline Formerly married & 11.1 & & 12.3 & & 11.0 & & 3.8 & \\
\hline \multicolumn{9}{|c|}{ Number of living children } \\
\hline 0 & 3.4 & 0.000 & 2.9 & 0.000 & 2.9 & 0.000 & 15.2 & 0.000 \\
\hline I & 6.0 & & 8.9 & & 5.8 & & 9.9 & \\
\hline $2-4$ & 7.7 & & 16.3 & & 9.0 & & 44.1 & \\
\hline$\geq 5$ & 11.2 & & 20.4 & & 10.1 & & 30.8 & \\
\hline
\end{tabular}

$\%$ is weighted 
Table III: Binary logistic regression analysis of factors associated with ever use of modern contraceptives among women aged I5-49 in NE and NW Nigeria

\begin{tabular}{|c|c|c|c|c|}
\hline & $\begin{array}{l}\text { Year } 1999 \\
\text { Adjusted } \\
\text { OR(95\%Cl) }\end{array}$ & $\begin{array}{l}\text { Year } 2003 \\
\text { Adjusted OR(95\%Cl) }\end{array}$ & $\begin{array}{l}\text { Year } 2008 \\
\text { Adjusted OR(95\%Cl) }\end{array}$ & $\begin{array}{l}\text { Year 20/3 } \\
\text { Adjusted } \\
\text { OR(95\% Cl) }\end{array}$ \\
\hline \multicolumn{5}{|l|}{ Region } \\
\hline NE & 1.00 & 1.00 & 1.00 & 1.00 \\
\hline NW & $2.15(1.47,3.14)$ & $1.64(1.30,2.08)$ & $0.74(0.64,0.86)$ & $1.30(1.12,1.50)$ \\
\hline \multicolumn{5}{|l|}{ Age } \\
\hline $15-19$ & 1.00 & 1.00 & 1.00 & 1.00 \\
\hline $20-24$ & $0.87(0.40,1.89)$ & $1.62(0.93,2.82)$ & $1.61(1.11,2.33)$ & $3.30(2.36,4.63)$ \\
\hline $25-29$ & $1.37(0.62,3.02)$ & $2.16(1.22,3.83)$ & $1.97(1.34,2.88)$ & $2.97(2.07,4.26)$ \\
\hline $30-34$ & I.64(0.70, 3.83) & I.84(I.0I, 3.35) & $1.90(1.27,2.86)$ & $3.50(2.38,5.13)$ \\
\hline $35-39$ & $2.07(0.86,5.00)$ & $1.94(1.04,3.60)$ & $1.43(0.93,2.20)$ & $3.00(2.00,4.48)$ \\
\hline $40-44$ & $0.59(0.19,1.81)$ & $1.52(0.80,2.91)$ & $\mathrm{I} .5 \mathrm{I}(0.97,2.35)$ & $2.86(1.87,4.37)$ \\
\hline $45-49$ & $0.72(0.21,2.49)$ & $\mathrm{I} .26(0.63,2.5 \mathrm{I})$ & $1.20(0.75,1.92)$ & $1.85(1.19,2.89)$ \\
\hline \multicolumn{5}{|l|}{ Residence } \\
\hline Urban & 1.00 & 1.00 & 1.00 & 1.00 \\
\hline Rural & $0.34(0.23,0.52)$ & $0.61(0.48,0.78)$ & $0.47(0.40,0.55)$ & $0.35(0.30,0.4 \mathrm{I})$ \\
\hline \multicolumn{5}{|l|}{ Highest education } \\
\hline $\begin{array}{l}\text { No formal } \\
\text { education }\end{array}$ & 1.00 & 1.00 & 1.00 & 1.00 \\
\hline Primary & $1.91(1.08,3.38)$ & $1.28(0.03,1.75)$ & $1.99(1.63,2.44)$ & $2.11(1.73,2.58)$ \\
\hline Secondary & $4.5 \mathrm{I}(2.59,7.87)$ & $3.34(2.40,4.64)$ & $4.16(3.36,5.13)$ & $3.06(2.5 \mathrm{I}, 3.73)$ \\
\hline Higher & $36.52(\mid 3.51,98.75)$ & $6.14(3.40,11.10)$ & $9.66(7.04,13.24)$ & $6.05(4.6 \mathrm{I}, 7.94)$ \\
\hline \multicolumn{5}{|l|}{ Religion } \\
\hline Christianity & 1.00 & 1.00 & 1.00 & 1.00 \\
\hline Islam & $0.15(0.09,0.24)$ & $0.37(0.26,0.53)$ & $0.30(0.25,0.36)$ & $0.09(0.08,0.12)$ \\
\hline Others & $0.29(0.04,1.90)$ & $0.38(0.10,1.4 I)$ & $0.46(0.27,0.79)$ & $0.09(0.03,0.32)$ \\
\hline \multicolumn{5}{|l|}{ Current working } \\
\hline No & 1.00 & 1.00 & 1.00 & 1.00 \\
\hline Yes & $1.53(1.03,2.28)$ & $1.61(1.29,2.03)$ & $1.19(1.02,1.38)$ & $1.59(1.36,1.86)$ \\
\hline \multicolumn{5}{|l|}{ Marital status } \\
\hline Never married & 1.00 & 1.00 & 1.00 & 1.00 \\
\hline Currently married & $3.04(1.00,9.22)$ & $1.69(0.73,3.91)$ & $1.59(1.03,2.47)$ & $0.50(0.34,0.73)$ \\
\hline Formerly married & $4.23(1.00,17.92)$ & $1.57(0.59,4.16)$ & $1.29(0.74,2.25)$ & $0.27(0.16,0.45)$ \\
\hline \multicolumn{5}{|l|}{$\begin{array}{l}\text { Number of living } \\
\text { children }\end{array}$} \\
\hline 0 & 1.00 & 1.00 & 1.00 & 1.00 \\
\hline 1 & $3.12(1.24,7.86)$ & $3.44(1.77,6.67)$ & $2.89(I .90,4.4 I)$ & $3.23(2.18,4.77)$ \\
\hline $2-4$ & $4.6 \mathrm{I}(1.90,11.15)$ & $5.91(3.11,11.25)$ & $4.69(3.10,7.10)$ & $5.72(3.89,8.39)$ \\
\hline$\geq 5$ & $5.24(2.01,13.68)$ & $8.45(4.32,16.53)$ & $6.40(4.11,9.98)$ & $7.44(4.93,11.22)$ \\
\hline
\end{tabular}


Table IV: Binary logistic regression analysis of factors associated with ever use of modern contraceptives among women aged I5-49 in NE and NW in I999, 2003, 2008 and 2013

\begin{tabular}{|c|c|c|c|c|c|c|c|c|}
\hline & \multicolumn{2}{|c|}{1999} & \multicolumn{2}{|c|}{2003} & \multicolumn{2}{|c|}{2008} & \multicolumn{2}{|c|}{2013} \\
\hline & $\mathrm{NE}$ & NW & $\mathrm{NE}$ & NW & $\mathrm{NE}$ & NW & NE & NW \\
\hline & Adjusted & Adjusted & Adjusted & Adjusted OR(95\%Cl) & Adjusted OR(95\%Cl) & Adjusted & Adjusted & Adjusted \\
\hline & $\mathrm{OR}(95 \% \mathrm{Cl})$ & $\mathrm{OR}(95 \% \mathrm{Cl})$ & $\mathrm{OR}(95 \% \mathrm{Cl})$ & & & $\mathrm{OR}(95 \% \mathrm{Cl})$ & OR(95\% Cl) & OR $(95 \% \mathrm{Cl})$ \\
\hline \multicolumn{9}{|l|}{ Age } \\
\hline $15-19$ & 1.00 & 1.00 & 1.00 & 1.00 & 1.00 & 1.00 & 1.00 & 1.00 \\
\hline $20-24$ & $0.50(0.16,1.58)$ & $1.30(0.43,3.92)$ & $2.8 \mathrm{I}(0.85,9.27)$ & $1.35(0.72,2.57)$ & $2.16(1.29,3.63)$ & $\mathrm{I} .20(0.7 \mathrm{I}, 2.04)$ & $2.34(1.20,4.55)$ & $4.55(3.00,6.89)$ \\
\hline $25-29$ & $0.76(0.24,2.39)$ & $2.16(0.68,6.83)$ & $4.35(I .29,14.72)$ & I.68(0.87, 3.25) & $2.32(1.35,3.99)$ & I.73(I.0I, 2.96) & $2.35(1.18,4.69)$ & $4.0 \mathrm{I}(2.56,6.28)$ \\
\hline $30-34$ & $0.96(0.29,3.20)$ & $2.36(0.68,8.13)$ & $3.79(1.07,13.40)$ & $\mathrm{I} .4 \mathrm{I}(0.70,2.86)$ & $1.95(1.08,3.52)$ & $\mathrm{I} .86(\mathrm{I} .05,3.28)$ & $2.99(1.46,6.15)$ & $4.25(2.64,6.86)$ \\
\hline $35-39$ & $1.47(0.42,5.16)$ & $2.45(0.68,8.82)$ & $3.06(0.83,11.33)$ & $\mathrm{I} .67(0.8 \mathrm{I}, 3.43)$ & $\mathrm{I} .34(0.72,2.5 \mathrm{I})$ & $\mathrm{I} .55(0.85,2.8 \mathrm{I})$ & $2.48(1.18,5.22)$ & $3.74(2.25,6.2 \mathrm{I})$ \\
\hline $40-44$ & $0.19(0.03,1.14)$ & $1.30(0.29,5.78)$ & $2.8 \mathrm{I}(0.73,10.77)$ & $1.24(0.58,2.64)$ & $1.31(0.68,2.52)$ & $1.65(0.89,3.04)$ & $1.99(0.91,4.35)$ & $3.89(2.29,6.63)$ \\
\hline $45-49$ & $0.40(0.06,2.53)$ & $1.20(0.22,6.5 \mathrm{I})$ & $1.99(0.49,8.10)$ & $1.19(0.53,2.68)$ & $1.3 \mathrm{I}(0.66,2.57)$ & $1.12(0.58,2.15)$ & $1.79(0.81,3.99)$ & $2.03(1.15,3.59)$ \\
\hline \multicolumn{9}{|l|}{ Residence } \\
\hline Urban & 1.00 & 1.00 & 1.00 & 1.00 & 1.00 & 1.00 & 1.00 & 1.00 \\
\hline Rural & $0.42(0.23,0.76)$ & $0.26(0.15,0.48)$ & $0.82(0.54,1.24)$ & $0.52(0.39,0.7 I)$ & $0.55(0.43,0.69)$ & $0.43(0.35,0.54)$ & $0.44(0.34,0.57)$ & $0.38(0.31,0.46)$ \\
\hline \multicolumn{9}{|l|}{ Highest } \\
\hline \multicolumn{9}{|l|}{ education } \\
\hline No formal & 1.00 & 1.00 & 1.00 & 1.00 & 1.00 & 1.00 & 1.00 & 1.00 \\
\hline \multicolumn{9}{|l|}{ education } \\
\hline Primary & $2.44(1.08,5.55)$ & I.52(0.68, 3.40) & $\mathrm{I} .33(0.8 \mathrm{I}, 2.20)$ & $1.26(0.83,1.91)$ & $2.08(1.56,2.76)$ & $1.91(1.43,2.54)$ & $2.42(1.77,3.32)$ & $1.91(1.46,2.49)$ \\
\hline Secondary & $5.97(2.76,12.93)$ & $3.56(1.53,8.27)$ & $4.20(2.36,7.47)$ & $3.07(2.05,4.62)$ & $3.50(2.54,4.83)$ & $4.66(3.5 \mathrm{I}, 6.20)$ & $3.39(2.45,4.70)$ & $2.67(2.06,3.47)$ \\
\hline Higher & $55.15(13.94,218.19)$ & $52.46(7.39,372.41)$ & $7.71(2.87,20.72)$ & $5.70(2.70,12.04)$ & II.68(6.92,19.7I) & $8.39(5.57,12.62)$ & $7.72(5.09,|I| .7 I)$ & $5.22(3.58,7.60)$ \\
\hline \multicolumn{9}{|l|}{ Religion } \\
\hline Christianity & 1.00 & 1.00 & 1.00 & 1.00 & 1.00 & 1.00 & 1.00 & 1.00 \\
\hline Islam & $0.13(0.07,0.26)$ & $0.18(0.09,0.36)$ & $0.40(0.25,0.64)$ & $0.36(0.20,0.62)$ & $0.49(0.37,0.64)$ & $0.18(0.14,0.24)$ & $0.24(0.18,0.32)$ & $0.06(0.05,0.07)$ \\
\hline Others & & & & $1.35(0.26,6.95)$ & $0.68(0.29,1.58)$ & $0.3 I(0.15,0.62)$ & $0.14(0.02,1.32)$ & $0.06(0.01,0.29)$ \\
\hline \multicolumn{9}{|l|}{ Currently } \\
\hline \multicolumn{9}{|l|}{ working } \\
\hline No & 1.00 & 1.00 & 1.00 & 1.00 & 1.00 & 1.00 & 1.00 & 1.00 \\
\hline Yes & $1.01(0.54,1.87)$ & $2.35(1.36,4.08)$ & $1.31(0.89,1.94)$ & $1.80(1.36,2.39)$ & $1.37(1.08,1.73)$ & I.19(0.97, I.45) & $1.67(1.29,2.15)$ & $1.83(1.48,2.25)$ \\
\hline
\end{tabular}


African Population Studies Vol. 29, No. 2, 2015

\section{Table IV continued}

\begin{tabular}{|c|c|c|c|c|c|c|c|c|}
\hline & \multicolumn{2}{|c|}{1999} & \multicolumn{2}{|c|}{2003} & \multicolumn{2}{|c|}{2008} & \multicolumn{2}{|c|}{2013} \\
\hline & $\mathrm{NE}$ & NW & $\mathrm{NE}$ & $\mathrm{NE}$ & $\mathrm{NE}$ & NW & NE & NW \\
\hline & Adjusted & Adjusted & Adjusted & Adjusted & Adjusted OR(95\%Cl) & Adjusted & Adjusted & Adjusted \\
\hline & OR(95\%Cl) & OR(95\%Cl) & OR(95\%Cl) & $\mathrm{OR}(95 \% \mathrm{Cl})$ & & OR(95\%Cl) & $\mathrm{OR}(95 \% \mathrm{Cl})$ & OR $(95 \% \mathrm{Cl})$ \\
\hline \multicolumn{9}{|c|}{ Marital status } \\
\hline Never & 1.00 & 1.00 & 1.00 & 1.00 & 1.00 & 1.00 & 1.00 & 1.00 \\
\hline \multicolumn{9}{|l|}{ married } \\
\hline Currently & $19.96(2.52,158.13)$ & $0.84(0.19,3.59)$ & $1.25(0.26,5.92)$ & I.64(0.58, 4.65) & $1.30(0.73,2.30)$ & $1.95(0.96,3.96)$ & $\mathrm{I} .08(0.57,2.0 \mathrm{I})$ & $0.211(0.12,0.38)$ \\
\hline \multicolumn{9}{|l|}{ married } \\
\hline Formerly & $34.99(2.15,388.54)$ & $0.83(0.11,5.99)$ & $1.82(0.34,9.73)$ & I.I3(0.3I, 4.07) & $0.97(0.45,2.1 \mathrm{I})$ & $\mathrm{I} .63(0.70,3.80)$ & $0.89(0.42,1.89)$ & $0.79(0.04,0.18)$ \\
\hline \multicolumn{9}{|l|}{ married } \\
\hline \multicolumn{9}{|c|}{ Number of } \\
\hline \multicolumn{9}{|c|}{ living children } \\
\hline 0 & 1.00 & 1.00 & 1.00 & 1.00 & 1.00 & 1.00 & 1.00 & 1.00 \\
\hline I & $2.28(0.63,8.30)$ & $4.82(1.27,18.26)$ & $5.25(1.30,21.14)$ & $3.1 \mathrm{I}(1.45,6.67)$ & $2.56(1.47,4.47)$ & $3.33(1.72,6.43)$ & $2.33(1.24,4.39)$ & $5.63(3.09,10.24)$ \\
\hline $2-4$ & $4.09(1.16,14.43)$ & $6.22(1.76,22.00)$ & $9.07(2.28,36.09)$ & $5.54(2.65,11.56)$ & $3.68(2.10,6.45)$ & $5.70(3.02,10.75)$ & $4.46(2.44,8.17)$ & $9.07(5.07,16.22)$ \\
\hline$\geq 5$ & $6.30(1.60,24.88)$ & $5.26(1.34,20.64)$ & $15.13(3.67,62.42)$ & $7.17(3.30,15.55)$ & $5.52(3.01,10.11)$ & $7.04(3.59,13.77)$ & $8.48(4.44,16.19)$ & $9.39(5.09,17.32)$ \\
\hline
\end{tabular}




\section{Discussion}

This comparative analysis of four NDHS data-sets (1999, 2003, 2008 and 2013) focused on the role of socio-economic determinants in reported ever use of modern contraceptives among women in the NE and NW GPZs of Nigeria. Consistently, the surveys established a positive relationship between women's socio-economic status and their reported use of modern contraceptives. Thus, as the women's socioeconomic status increased, their reported use of modern contraceptives also increased.

Age at marriage and age at sexual debut are key determinants of the number of childbearing years to which women are exposed. These factors are important to the extent that "in a society where contraception is hardly ever used and women are strictly kept apart from any sexual relationship outside marriage, a rise in the marriage age is automatically a factor for lower fertility" (WHO, 2000) Age affects fertility, pregnancy, childbearing, women's opportunities for educational and economic empowerment and invariably the ability to support their families, children and themselves. Except for 2003, the models reveal higher contraceptive use in the NW across all age groups. However, there is noticeable concentration in reported ever use of modern contraceptives around age groups $25-39$, which appears to contradict the high and persistent TFR pattern reported in the models. There is the likelihood that reported contraceptive use was more for spacing than limitation because children are still seen as symbols of wealth, sources of free farm labour and have intrinsic value in most communities of northern Nigeria. Indeed, younger women (I5 19) were shown to be less likely to use modern contraceptives (Table II) perhaps due to stronger socio-religious expectations of childbearing from them. The dominant religion (Islam) supports polygynous marriage, which is known to foster competition for childbearing among co-wives, especially of male children, to consolidate their positions in the household.

Women resident in urban areas consistently reported higher contraceptive use compared to their rural counterparts. Undoubtedly, women's socioeconomic status matter, although it certainly counts for less without the opportunity for access created by the concentration of health facilities and qualified FP providers in Nigeria's urban settings. Moreover, most health expansion and demand creation programmes by government and the private sector take place in the urban areas of Nigeria. Urban women also have more frequent exposure to behavioural change communication (BCC) messages and other media (Bankole, 1994). Yet, more Nigerian women of childbearing age reside in the rural areas where the primary health care (PHC) structures on which they depend are quite weak. Functioning PHCs are far apart, posing a serious access challenge arising from bad roads and high cost of transportation in rural areas (PATHS2, 20I4). Shortage of contraceptive commodities and consumables, dearth of qualified nurses/midwives and PPFP competences (ARFH, 2014; WHO, 2014; State of the World Midwifery, 20I4), incorrect perceptions about side effects (Chikovore et al., 2002; Kaler, 2000; Gululethu, 1994), poor provider remuneration and socio-cultural barriers such as husband's consent or spousal disapproval (Tantawy and Hassan 200I; Nwachukwu and Obasi, 2008) also hinder the use of contraceptives.

Apart from 2008 where women of secondary education represented the highest use levels, the other models revealed progressively higher contraceptive use by level of education for women in the NE GPZ. Female education is considered "the most influential investment that can be made in the developing world" (WHO, 2000). It enables women to participate in gainful employment, contribute to the nation's growth, promote smaller families and generally improve the use of contraceptives (Table II) and the health of children. Furthermore, "women with more education usually make a later, healthier transition into adulthood: they have their first sexual experience later, marry later, want smaller families, and are more likely to use contraception than their less educated counterparts" (WHO, 2000). A visible pattern that emerged from all the models is the reported low use of contraceptives by women with no education (Table IV), which likely contributed to the steadily high TFR in these GPZs. The 2013 data indicates that though the proportions of women with no formal education in the NE (64\%) and NW (69\%) are large (Table I), they account for only 25 percent of reported contraceptive use (Table II).

Islam is the predominant religion of the women (Table I) who generally reported low contraceptive use, particularly in the NW models (Table IV). Religion is critical to behavioural change and it is regrettable that policy-makers and programme planners have not adequately harnessed it to promote contraceptive use in northern Nigeria. Algeria, a predominantly Islamic society with one of the world's highest population growth rates (3.2\%) in the mid-1960s, presents a classic illustration of a country where the social change potentialities of religion were tapped to promote contraceptive use for birth spacing (McNicoll et al. 20I2). To achieve this, the Algerian government transited from an initial denunciation of population policy to establishment of birth spacing centers while insisting that 
"development is the best contraceptive." There was also the call in 1966 by the National Union of Algerian Women (UNFA) to recognise their rights to FP, which the president supported. But more importantly, it was the fatwa issued by the Algerian High Islamic Council in 1968, renewed in 1982, which provided the main motivation for the voluntary use of reversible contraception for birth spacing that it endorsed. Basically, the fatwa encouraged policymakers who "no longer feared negative reaction from religious authorities" to venture into full scale population policy. Thus, even before the Algerian government came up with its first national population policy in 1983, the country's TFR had decreased from 8.1 in 1970 to 5.3 children in 1981.

Several windows of opportunity have opened up for Nigeria to replicate the Algerian experience but they remain unexplored. One of these is documented as a report of esteemed scholars who gathered to deliberate on the Islamic perspectives on "reproductive health issues in Nigeria" and issued a fatwa for the termination of life-threatening pregnancies (NURHI, 2004). In the same vein, during the Family Planning Action Group (FPAG) discussions at the second National FP conference in Nigeria (20I2), a notable northern leader and custodian of Islam disclosed that FP is an "Islamic right" dating back to the period of Prophet Muhammad. Thus, there is no Islamic or religious justification for "bearing of children to the street" (the phenomena of Almajiris or impoverished immigrant Koranic pupils) because they become vulnerable to "negative circumstances in the name of seeking for religious knowledge or other social reasons." $\mathrm{He}$ then surmised that "for a woman who is medically and professionally advised to adopt family planning due to a recognised need, Islam has no counter argument to that. The total output should be a healthy mother and child that should be able to contribute positively to the development of the society, not street children falling into various spheres of social vices" (Shokunbi, 2014). Another backing for FP based on the Quran states that "contraception helps families achieve tranquility by having children when they want them and when they are prepared to have them" (RoudiFahimi, 2004). Furthermore, scholars of Islamic jurisprudence affirm that "Islam is a religion of moderation and point to the principles of "liberty" or "permissibility" in Islam - that is, everything is lawful unless explicitly designated otherwise in the Quran or in the prophet's tradition (Sunnah)" (Orman, 1992).

But, what in our view constitutes the most apparent lead for policy-makers and programme planners to latch on to expand the use of contraceptives in northern Nigeria is the deduction by these scholars that God is "All-Knowing" and could not have excluded the matter of contraception unintentionally. Therefore, "if excessive fertility leads to proven health risks for mothers and children, or economic hardship and embarrassment for the father, or the inability of parents to raise their children properly, Muslims would be allowed to regulate their fertility in such a way as to reduce these hardships" (Orman, 1992). Some overarching issues that have emerged from the discourses are that Islam is not averse to FP and modern contraceptives may be used to achieve greater wellbeing particularly as it borders on the health of women and children, health care quality and family financial management considerations.

Currently working women were more likely to report higher contraceptive use (Table IV) though the odds favoured the NW in the models. The proportion of these women increased from $20 \%$ in the baseline year (1999) to $46 \%$ (NE) and $57.6 \%$ (NW) in 2013 (Table I), conforming to the steady increase in reported contraceptive use for the same period (Table II). The implications of this trend are that as more women engage in work the CPR will increase accordingly in northern Nigeria. This is because work, specifically paid employment outside the home empowers women to exercise their rights to contraceptive choice, procurement and confidential use in settings where socio-religious norms encourage childbearing (World Bank, 2000). For instance, the preference for injectable contraceptives over pills in sub-Saharan Africa (SSA) has frequently been attributed to its concealability potentials during use, (Sule et al. 2006; World Bank, 2000; Asharaf et al. 2003).

Apart from the rather unusually high odds in the 1999 model for the NE, the currently married women from the NW (2003 and 2008) reported higher contraceptive use. On the other hand, the 2003 and 2013 surveys reported better odds for the formerly married women of the NE. It is understandable for the never married and formerly married to use contraceptives due to societal expectations that childbearing should occur in marriage. In addition to this, it is also likely that the formerly married category could be made up of women who already have their desired number of children or who do not want the responsibility that comes with an additional child.

In all the survey years, reported contraceptive use increased as the parity or women's number of living children increased (Table IV). But, at all the levels of parity ( $I-5$ children), the odds favoured the NW in 2008, 2013 and 1999 (at I and 2 -4), while the NE had the advantage in 2003. This is understandable as families find that with increasing cost of food, clothing, shelter, quality education, medicines, and 
transportation providing quality care for each additional child becomes ever more challenging.

\section{Conclusion}

Generally, the observed odds for contraceptive use favoured the NW, but the difference is not wide enough for us to conclude that this region is far ahead of the NE GPZ. Overall, based on the main findings presented in this study, a logical recommendation would be to prioritise improvement of the socioeconomic status of the women in northern Nigeria to, at least, empower them to understand and exercise their rights to use modern contraceptives to either delay, space or limit childbearing. However, as the series of survey datasets that guided this study portrays, the socio-economic status of women in the north has remained consistently low regardless of numerous empowerment programmes, indicating the need for greater attention on another set of dynamics. Islam, which we identify as the most critical of these dynamics in northern Nigeria, is a way of life and for women it defines the common contexts within which their behaviour is considered acceptable or anomic. It (Islam) practically dictates what is considered normative in other social structures and institutions (e.g. the political, economic, educational, legal, health care, marriage, banking, etc.). Therefore, while we encourage positive proclamations (Fatwa) such as the one issued by the Algerian High Islamic Council, efforts should also be made to identify ways in which women in these GPZs could participate in socio-economic life that are consistent with their socio-religious expectations. It is not unlikely that the fatwa issued by Islamic scholars in this country failed because it did not resonate beyond the document in which it was captured. Fatwa could be more effectively used to enrich the Islamic educational system with programmes for women empowerment that are tied to economic opportunities in the study GPZs and simultaneously correct the wrong impression held by women who have had only Islamic education that the use of modern contraceptives is un-Islamic. (Sule et al. 2006; World Bank, 2000). Functional Islamic education that is relevant to active participation and earnings in the formal and informal work sectors will likely empower women to exercise their full reproductive rights including the use of contraceptives. An educationally and financially empowered woman is unlikely to wait for her husband's/in-laws' consent before taking measures, including FP, to improve her health and that of her children. Such religious proclamations should make school attendance compulsory with the support of government given that female education increases the age at marriage and at first pregnancy/birth, contraceptive knowledge and use and child spacing practices (World Bank, 2000).

At the level of the health system, it has become clear that the challenge of human resources for health is very critical to stimulating increased demand for and use of contraceptives in northern Nigeria. Government should as a matter of urgency, invest in the training of "medically and professionally" competent health personnel, particularly women, provide them with special incentives and deploy them to all primary health care (PHC) facilities in the rural areas of northern Nigeria. Efforts should be made to integrate FP services into functional antenatal, immunization, baby-friendly, PMTCT and other facility and community-based health care programmes. Furthermore, in order for government to demonstrate the seriousness of its intentions to raise the country's CPR from the present level (10\%) to $36 \%$ in 2018 , it needs to revive all non-functioning PHCs, construct new/rehabilitate bad roads and operate subsidized transport services in order to improve access to FP services in the rural areas of northern Nigeria.

\section{References}

Adebowale S. et al. (2013) Contraceptive Use among Nigerian Women with no Fertility Intentions: Interaction amid Potential Causative Factors. African Population Studies 27(2).

Asharaf, Nava., Field, E., and Lee, J. (2003), Household Bargaining and Excess Fertility: An Experimental Study in Zambia. Accessed from: http://www.povertyactionlab.org/publication/hous ehold-bargaining-and-excess-fertility-

experimental-study-zambia. (Accessed: 9th December: 2014).

Bankole, A. (1994) The Role of Mass Media in Family Planning Promotion in Nigeria. DHS Working Papers, Demographic and Health Surveys, MARCO International.

Caldwell, J. C. and Caldwell, P. (1977) The Role of Marital Sexual Abstinence in Determining Fertility: a Study of the Yoruba in Nigeria. Population Studies, 3 I (2): 193-2I7.

CBN (2002), Annual Report and Statement of Accounts, Central Bank of Nigeria, Abuja.

Chikovore, J., Landmark, G., Nystrom, L., Mbizzo, M. T., Ahlberg, B. M. (2002) The Hide-and-Seek Game: Men's Perspectives on Abortion and Contraceptive Use within Marriage in a Rural Community in Zimbabwe. Journal of Biosocial Science 34: 317-332.

Duze, M. C., and Mohammed Z. I. (2006) Male Knowledge, Attitudes, and Family Planning 
Practices in Northern Nigeria. African Journal of Reproductive Health, I0(3): 53-65.

Erulkar, A. and Bello M. (2007) The Experience of Married Adolescent Girls in Northern Nigeria. Abuja: Population Council and Kano: AHIP.

Ouadah-Bedidi, Z., Vallen, J. (20I2) Fertility and Population Policy in Algeria: Discrepancies between Planning and Outcomes. In Geoffrey McNicoll, John Bongaarts, and Ethel P. Churchill. Population and Public Policy: Essays in Honor of Paul Demeny, Population and Development Review, A Supplement to Volume 38, Population Council, New York.

Fotso J.C., Ajayi J.O., Idoko E.E, Speizer I., Fasiku D.A., Mberu B. \& Mutua M. (20II) Family Planning and Reproductive Health in Urban Nigeria: Levels, Trends and Differentials. Chapel Hill, NC: Measurement, Learning \& Evaluation (MLE) Project [UNC, USA] and National Population Commission (NPC) Nigeria.

Gule, Gugulethu, (1994) Socio-Cultural Constraints to Family Planning in Swaziland. Canadian Studies in Population, 21 ( I):35-49.

FMOH (2013). Increasing Access to Long-Acting Reversible Contraceptives in Nigeria: National Strategy and Implementation Plan (2013 -20/5), Federal Ministry of Health, Abuja.

http://worldpopulationreview.com/countries/nigeriapopulation/ (Accessed: 24 ${ }^{\text {th }}$ October 2014).

http://www.arfh-ng.org/news/item0 I 2.php; www.stateoftheworldmidwifery.com

December: 20I4).

http://www.dailymail.co.uk/health/article-

2198 |24/Fears-hundreds-contraceptive-implantsgone-missing-womens-bodies-putting-fertilityrisk.html (Accessed 6 ${ }^{\text {th }}$ December 20l4).

http://www.irinnews.org/report/93340/nigeriachanging-attitudes-to-contraception (Accessed: $16^{\text {th }}$ November 2014)

Izugbara, C., Ibisomi, L. Ezeh, A. C., Mandara, M. (2010), Gendered Interests and Poor Spousal Contraceptive Communication in Islamic Northern Nigeria. Journal of Family Planning and Reproductive Health Care, 36: 219-224.

Kaler, A. (2000) "Who Has Told You to Do This Thing?" Toward a Feminist Interpretation of Contraceptive Diffusion in Rhodesia, 1970-1980. Signs, 2000, 25 (3).

Makinwa-Adebusoye, P. and Kritz, M. (1995). Women's Decision-Making Inputs. Spousal Agreement and Family Planning in Nigeria. Paper presented at the 1995 Annual Meeting of the Population Association of America, San Fransisco, CA.
Mensch B, Bruce J. Greene M. (1988) The Uncharted Passage: Girls' Adolescence in the Developing World, New York: Population Council.

Nair, P. S. and Navaneetham, K. Patterns and Determinants of Modern Contraceptive Use in Southern, Africa, http://iussp.org/sites/default/files/event_call_for_p apers/Patterns\%20

and\%20determinants\%20of\%20contraceptive\% 20practice_aug24.pdf (Accessed: II th December 2014).

National Population Commission and ORC Macro (2000) Nigeria Demographic and Housing Survey 1999. Calverton, MD, USA: National Population Commission and ORC Macro.

National Population Commission and ORC Macro (2004) Nigeria Demographic and Housing Survey 2003. Calverton, MD, USA: National Population Commission and ORC Macro.

National Population Commission and ORC Macro (2009) Nigeria Demographic and Housing Survey 2008. Calverton, MD, USA: National Population Commission and ORC Macro.

National Population Commission and ORC Macro, (2014) Nigeria Demographic and Housing Survey 20/3. Calverton, MD, USA: National Population Commission and ORC Macro.

Ndep, O. A. (2014) Informed Community Participation is Essential to Reducing Maternal Mortality in Nigeria, International Journal of Health and Psychology Research, 2(I): 26-33.

NURHI (2004) Reprint of the Reproductive Health Issues in Nigeria: The Islamic Perspectives, Pathfinder International and POLICY Project, Abuja.

Odimegwu C. O, Modupe O, Siyagande A. (1997) Regional Correlates of Contraceptive Methods in Nigeria. Journal of Population and Development, 26(I):129-145.

http://www.un.org/esa/population/publications/prosp ectsdecline/dodoo.pdf (Accessed: 24 ${ }^{\text {th }}$ October 20|4).

Odimegwu, C. O. (1994) Some Determinants of Contraceptive Behaviour in Bendel State Nigeria. Journal of the Population Association of Nigeria, 2(I): 35-48.

Olurode, L. (1998) Impact of Social Change on Reproductive Choice in Nigeria: A Study of Muslim Women in Purdah. In Serour G. I. (ed.), Proceedings of the International Conference on Population and Reproductive Health in the Muslim World, February 2I-24, Cairo: Al-Azhar University: 346-59.

Federal Ministry of Health, (2004). Family Planning Training for Physicians and Nurses/Midwives in 
the Private Sector: National Training Manual, FMOH, Abuja.

Omo-Aghoja L. O, Omo-Aghoja V. W, Aghoja C. O, Okonofua F. E, Aghedo O, Umueri C (2009). Factors associated with the Knowledge, Practice and Perceptions of Contraception in Rural Southern Nigeria. Ghana Medical Journa/43(3).

Omran, A. R. (1992) Family Planning in the Legacy of Islam, (London: Routledge).

Oyedokun A. O. (2007). Determinants of Contraceptive Usage: Lessons from Women in Osun State, Nigeria Journal of Humanities and Social Sciences, I (2): I-I4.

Population Bureau, 2009 World Population Data Sheet, Washington: Population Bureau. http://www.prb.org/Publications/Datasheets/2009 wpds.aspx (Accessed: 24 ${ }^{\text {th }}$ October 2014)

Roudi-Fahimi, F. (2004) Islam and Family Planning. MENA Policy Brief, Population Reference Bureau.

Shokunbi, Y. (2014) Role of Family Planning in National Development. Daily Independent, Wednesday, July 02, 2014.

Sule, T. S., Umar, H. S. Madugu, N. H. (2006) Knowledge and Use of Modern Contraception among Muslim Women in Zaria, Nigeria, Journal of Indian Medical Association, 38(I0).

Tantawy, A. B., Hassan, F. I. (200I) Study of Unmet Need of Family Planning and Response to Health Education among Women at Reproductive Age. Population Science, 25: 5 - 64.
Nwachukwu, lke. Obasi (2008). Use of Modern Birth Control Methods among Rural Communities in Imo State, Nigeria. African Journal of Reproductive Health I2(I): I0I-108

The Partnership for Transforming Health Systems Phase Two (PATHS2). Empowering Communities, Saving Lives: Investing in Sustainable Health Care Services in Nigeria, UKAID, Abuja.

Van de Walle, E and Van de Walle, P. (1989), "Postpartum Sexual Abstinence in Tropical Africa." Working Paper No. 17 African Demography Working Papers, Population Studies Training Centre, University of Pennsylvania, USA.

Wall L. L. (1998). Dead Mothers and Injured Wives: The Social Context of Maternal Morbidity among the Hausa of Northern Nigeria, Studies in Family Planning, 29(4): 34I-359.

World Bank, (2000), Is Education the Best Contraceptive? Population Reference Bureau Measure Communication, 1875, Washington, DC 20009 USA: http://www.prb.org/pdf/lsEducatContracept_Eng.pdf (Accessed: $5^{\text {th }}$ November 20|4).

www,who.int/reproductivehealth/topics/family_plann ing/statement_collective/_Action.pdf (Accessed: October 2014).

www.stateoftheworldmidwifery.com (Accessed: $12^{\text {th }}$ December 2014).

http://www.who.int/mediacentre/factsheets/fs35I/en/ (Accessed: 14-January 2015). 